PUZZLE

\title{
'Kross Word'
}

Vinodhini R, Asha Marie Ambroise, Interns, IGIDS

\begin{tabular}{|c|c|c|c|c|c|c|c|c|c|c|c|c|c|c|c|}
\hline 1 & & & & 2 & & & & & 3 & & 4 & & & & \\
\hline & & & & & & & 5 & & & & & & & & \\
\hline & & & & & & 6 & & & & & & & & 7 & \\
\hline & & 8 & & & & & & & & & & & & & \\
\hline & & & & & & & & & & 9 & & & & & \\
\hline 10 & & & & & & & & 11 & & & & & & & \\
\hline & & & & & & & & & & & & & & & \\
\hline & & & & & & 12 & & & & & & & & & \\
\hline & & & & & & & & & & & & & & & \\
\hline 13 & & & & & & & & & & & & & & & \\
\hline & & & & & & & & & & & & & & & \\
\hline 14 & & & & & & & & & 15 & & & 16 & & 17 & \\
\hline & & & & & & & & & & & & & & & \\
\hline & & & & & & & & & & & & & & & \\
\hline & & & & & & & & & & & & & & & 18 \\
\hline 19 & & & & & & & & & & & & & & & \\
\hline & & & & & & & & & & & & & & & \\
\hline & & & & & & & & & & 20 & & & & & \\
\hline & 21 & & & & & & & & & & & & & & \\
\hline & & & & & & 22 & & & & & & & & & \\
\hline & 23 & & & & & & & & & & & & & & \\
\hline & & & & & & & & & & & & & & & \\
\hline & 24 & & & & & & & & & & & & & & \\
\hline & & & & & & & & & & & & & & & \\
\hline
\end{tabular}

\section{ACROSS}

1) Organically modified ceramic (8)

3) He introduced HBSS in endodontics (7)

6) Type of fracture where one cortex is broken and opposite is bent (10)

9) Para-trigeminal syndrome (other name) (6)

10) Material used in pit\& fissure sealants (14)

13) A cause of intrinsic stain due to hyperbilirubinemia $(7,7)$

14) Platinum reinforced one piece porcelain bridge (5)

19) Instrument for measuring the force exerted on closing the jaw (17)

20) Used in regenerative osseous surgery (8)

21) Silver powder mixed with GIC powder (6)

22) Test to select the tooth shade $(6,4)$

23) He formulated pedodontic triangle $(1,1,5)$

24) Radioresistant malignant tumour (12)

\section{DOWN}

2) Condition related to periodontium which does not respond to any treatment $(10,13)$

4) Similar to koch postulate in periodontics (9)

5) Modified lysosomes in st.spinosum (13)

7) A variant of chronic osteomyelitis with periosteal inflammatory reaction (5)

8) Impact of blunt trauma (9)

11) Bite achieved by bringing mandible forward in class-II div-I (6)

12) Uncommon inflammatory odontogenic cyst on buccal aspect of mand. 1st molar $(10,4)$

15) Radiographic feature of cherubism $(8,5)$

16) Riapt tuhom (anagram)-pertains to lips $(5,5)$

17) Design used primarily for incipient proximal carious lesion in anterior teeth (8)

18) Hypertrophied muscle in bruxism patient (8)

\begin{tabular}{|c|c|c|c|}
\hline & 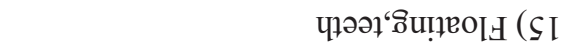 & \multicolumn{2}{|c|}{ ІәрәшошеиКрочрей (6 I } \\
\hline $\mathbf{A}$ & 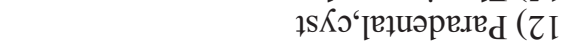 & & UUeMS $(\triangleright I$ \\
\hline $\mathbf{N}$ & Kepuns ( I I & 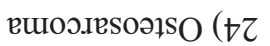 & 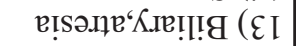 \\
\hline $\mathbf{S}$ & uotsmuop (8 & Чเ!. $M^{6} Z^{6} D(\varepsilon Z$ & 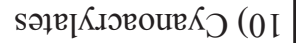 \\
\hline $\mathbf{W}$ & IəџəSSEW (8I & 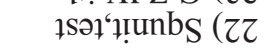 & .әрәху $(6$ \\
\hline W & 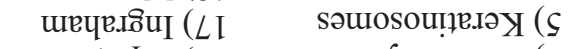 & ๆอนเวว (I & 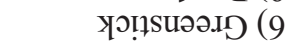 \\
\hline $\mathbf{E}$ & 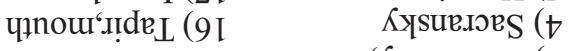 & sse[ôo!̣ (0Z & Jəuse. \\
\hline $\mathbf{R}$ & 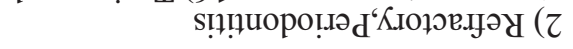 & & .əэошіо ( I \\
\hline $\mathbf{S}$ & uмo & & SSOIOV \\
\hline
\end{tabular}

